\title{
Clinical Reasoning: A 59-Year-Old Man With Progressive Proximal Weakness Since Childhood
}

Long Davalos, MD, Jacqueline Janecek, MD, Yelena Fudym, DO, Paul McKeever, MD, and Brian C. Callaghan, MD

Neurology ${ }^{\circledR}$ 2021;97:958-963. doi:10.1212/WNL.0000000000012488
Correspondence

Dr. Davalos

long.davalos@gmail.com

\section{Section 1}

A 59-year-old man presented with slowly progressive weakness. During childhood, he had difficulty climbing stairs. At age 30 years, he noted difficulty getting out of a chair or standing up from the floor without using his arms. At age 48 years, he started having 3-4 falls per year. He denied orthopnea and dyspnea. He had well-controlled hypothyroidism and hyperlipidemia. Medications included levothyroxine and niacin, and he denied the use of statins, fibrates, steroids, and alcohol intake. His parents (unrelated), sister, and 2 sons (aged 16 and 18 years) had no weakness. His maternal grandfather had leg weakness with difficulty climbing stairs around age 30 years and was using a wheelchair by age 60 years.

Examination revealed atrophy in the bilateral quadriceps. Tone was normal, and no fasciculations were present at rest or with muscle contraction. Cranial nerves were intact without facial weakness. He had mild bilateral biceps weakness (Medical Research Council [MRC] grade 4) and moderate symmetric proximal lower extremity weakness (MRC grade 3-4) in the iliopsoas and quadriceps. His infraspinatus, deltoids, triceps, and distal muscles had normal strength. Clinical myotonia was not observed. Tendon reflexes were reduced throughout. He was unable to rise from a seated position without using his arms. His gait was slow with a decreased stride length and narrow base. Sensory examination was normal.

\section{Questions for Consideration:}

1. Where would you localize this process?

2. Is this an acquired or inherited disease?

3. What testing would be helpful to narrow the differential?

\section{GO TO SECTION 2}




\section{Section 2}

Given the lack of sensory involvement, possible localizations include anterior horn cells, motor nerve roots, neuromuscular junction, and muscles. His presentation of symmetrical biceps and lower extremity proximal weakness is most consistent with a myopathy. Neuromuscular junction conditions such as myasthenia gravis or congenital myasthenia syndrome, and less frequently, anterior horn cell diseases such as spinal muscular atrophy type 3 and 4 , can also present in this way. The absence of fasciculations or prominent atrophy makes an anterior horn cell condition less likely, and the lack of fatigability argues against a neuromuscular junction disease. The childhood onset, along with the slowly progressive symptoms, makes an inherited myopathy most likely. The patient's maternal grandfather is also affected, and his parents, sister, and sons spared, which increases the possibility of $\mathrm{X}$-linked recessive inheritance. In X-linked recessive disorders, male-to-male transmission is never present, and the daughters of affected individuals are obligate carriers.
Creatine kinase (CK) levels may be helpful in localization. An elevated CK level usually localizes the problem to the muscle, although anterior horn cell diseases can also show mild CK elevations. However, a normal CK level can be seen in many inherited myopathies. Electrodiagnostic testing would help differentiate between a myopathy, neuropathy, and neuromuscular junction disorder. An EKG and an echocardiogram can evaluate for cardiac involvement. His serum CK was mildly elevated (281-554 IU/L; normal $<240 \mathrm{IU} / \mathrm{L}$ ). EMG showed abnormal spontaneous activity, diffuse myotonic discharges, and widespread myopathic motor units. Nerve conduction studies were normal. EKG showed a first-degree AV block, and the echocardiogram was normal.

\section{Questions for Consideration:}

1. Based on these findings, what is the differential diagnosis?

2. What additional testing would you perform to clarify the diagnosis? 
Table Differential Diagnosis for Inherited Muscle Disorders With a Progressive Limb-Girdle Weakness Phenotype and Diffuse Electrical Myotonic Discharges

\begin{tabular}{|c|c|c|c|}
\hline & Myotonic dystrophy type II & Late-onset pompe disease & $\begin{array}{l}\text { X-linked myopathy with } \\
\text { excessive autophagy }\end{array}$ \\
\hline Etiology & CCTG repeat expansion in the ZNF9 (CNBP) gene. & $\begin{array}{l}\text { Glycogen storage disorder. GAA gene mutation } \\
\text { causes GAA deficiency. }\end{array}$ & $\begin{array}{l}\text { Autophagic vacuolar myopathy } \\
\text { due to VMA21 gene mutation. }\end{array}$ \\
\hline $\begin{array}{l}\text { Inheritance } \\
\text { pattern }\end{array}$ & Autosomal dominant & Autosomal recessive & X-linked recessive \\
\hline Age at onset & Second to seventh decade & After age 12 months & First and second decade \\
\hline $\begin{array}{l}\text { Clinical } \\
\text { presentation }\end{array}$ & $\begin{array}{l}\text { Proximal weakness affecting primarily neck flexors, } \\
\text { hip flexors, and hip extensors. Prominent pain } \\
\text { described as aching or stiffness. Can present } \\
\text { clinical myotonia. }\end{array}$ & $\begin{array}{l}\text { Proximal weakness affecting primarily hip } \\
\text { extensors, flexors, and adductors. Paraspinal and } \\
\text { abdominal weakness. Respiratory involvement. } \\
\text { Lumbar hyperlordosis. }\end{array}$ & $\begin{array}{l}\text { Proximal weakness primarily in the } \\
\text { lower extremities. No clinical } \\
\text { myotonia. }\end{array}$ \\
\hline Treatment & No specific treatment available & Alglucosidase alfa (enzyme replacement therapy) & No specific treatment available \\
\hline $\begin{array}{l}\text { Similarities } \\
\text { to the case }\end{array}$ & Proximal weakness and electrical myotonia & Proximal weakness and electrical myotonia & $\begin{array}{l}\text { Proximal weakness, inheritance } \\
\text { pattern, and electrical myotonia }\end{array}$ \\
\hline $\begin{array}{l}\text { Differences } \\
\text { from the } \\
\text { case }\end{array}$ & $\begin{array}{l}\text { Inheritance pattern. Cases can present without } \\
\text { pain or clinical myotonia. }\end{array}$ & $\begin{array}{l}\text { Inheritance pattern, no respiratory involvement. } \\
\text { Some cases can present with only subtle } \\
\text { respiratory involvement. }\end{array}$ & $\begin{array}{l}\text { Isolated biceps weakness in the } \\
\text { upper extremities and sparing } \\
\text { scapular and deltoid muscles is } \\
\text { unusual. }\end{array}$ \\
\hline
\end{tabular}

Abbreviation: acid alpha-glucosidase.

\section{Section 3}

The clinical history, CK elevation, and myopathic features on EMG are consistent with an inherited muscular disease. Differential diagnosis for inherited muscle disorders with progressive limb-girdle weakness and diffuse myotonic discharges includes myotonic dystrophy type 2 (DM2), and vacuolar myopathies, particularly Pompe disease and X-linked myopathy with excessive autophagy (XMEA) (Table). ${ }^{1-3}$ Myofibrillar myopathies can exhibit vacuolar changes as well and clinically present in a similar fashion. ${ }^{4}$ Rarely, limb-girdle muscular dystrophy (LGMD) 2A (calpainopathy), LGMD 2B (dysferlinopathy), and LGMD 2L (anoctamin) can present with electrical myotonia. ${ }^{1}$

The presence of diffuse myotonia should prompt consideration of nondystrophic myotonias, such as myotonia congenita, paramyotonia congenita, and hyperkalemic periodic paralysis.
However, these patients typically present with episodic symptoms and clinical myotonia, which differs from this case.

Given the possible X-linked inheritance pattern and proximal weakness, Becker muscular dystrophy should be considered. However, these patients typically present with prominent cardiomyopathy and without electrical myotonia. ${ }^{1}$

At this point, testing of acid alpha-glucosidase (GAA) activity and CCTG repeat expansion in the ZNF9 gene would be helpful in diagnosing Pompe disease and DM2, respectively. If these tests are not conclusive, a muscle biopsy could lead to diagnostic clues.

GAA activity and genetic testing for DM2 were normal. Muscle biopsy of the right vastus lateralis is shown in the Figure. The myopathic features (rounded fibers, scattered split fibers, and internalized nuclei) and prominent adipose infiltration

Figure Vastus Lateralis Muscle Biopsy

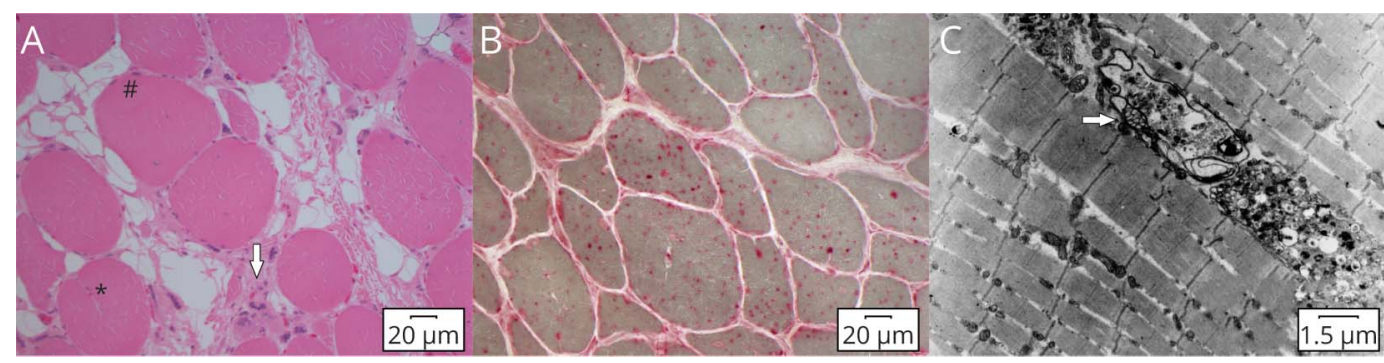

(A) Hematoxylin and eosin stain showing aggregates of severely atrophic (arrow), rounded fibers and adjacent hypertrophic fibers(\#), split fiber ( ${ }$ ) and adipose infiltration into fascicles. (B) Acid phosphatase enzyme histochemistry showing diffuse red punctate vacuoles within the fibers, which represent lysosomal enzyme reactivity. (C) Electron microscopy showing an enlarged autophagic vacuole (arrow) with accumulated myelinoid, multilamellar, vacuolar, granular and dense material, and intact myofibrillar apparatus. 
indicated a chronic muscle condition (dystrophy). Electron microscopy showed an abundance of variably sized autophagic vacuoles. There was no accumulation of glycogen seen on periodic acid-Schiff. The described combination of features represented a chronic myopathy with excessive autophagy.

\section{Questions for Consideration:}

1. Based on the muscle biopsy findings, what is the differential diagnosis?

2. What additional testing would help determine the definite diagnosis?

GO TO SECTION 4 


\section{Section 4}

The 3 best-defined autophagic vacuolar myopathies are Pompe disease, Danon disease, and XMEA.

Late-onset Pompe disease is unlikely because there was no glycogen excess on PAS or electron microscopy and the GAA activity was normal. Danon disease is an X-linked dominant disease secondary to LAMP-2 mutations that typically presents with mild progressive proximal weakness, hypertrophic cardiomyopathy, cognitive impairment, and frequently, pigmentary retinopathy. ${ }^{5}$ The lack of heart, ocular, and cognitive involvement makes this less likely.

XMEA is an X-linked recessive disorder that usually presents in the first 2 decades of life. The progression is very slow, and many patients are still ambulatory after age 50 years. There is no cardiac or cognitive involvement, which helps in differentiating it from Danon disease, and the EMG typically shows diffuse myotonia despite the absence of clinical myotonia. ${ }^{3}$ Based on the clinical phenotype, inheritance pattern, EMG findings, and histologic features, XMEA was suspected. The gene for this condition was not yet identified at the time of diagnosis, but later became known. VMA21 sequencing revealed a pathogenic hemizygous mutation consisting of a single nucleotide substitution (Exon 3, c. $6 A>G)$. This variant has been observed in different families affected with XMEA, which confirmed the diagnosis. ${ }^{6}$

\section{Discussion}

This case highlights the importance of integrating the clinical phenotype, electrodiagnostic findings, and histologic features when determining the etiology of an inherited myopathy. The presence of diffuse electrical myotonia indicates hyperexcitability of the muscle membranes and may reflect structural sarcoplasmic changes. Besides myotonic dystrophy, vacuolar myopathies should also be considered in patients with progressive weakness and electrical myotonia, especially if there is no evidence of clinical myotonia.

Genetic testing options for neuromuscular disorders have recently grown significantly. The implementation of phenotypicspecific gene panels, such as muscular dystrophy panels that include LGMD and XMEA, has increased the diagnostic yield in individuals with inherited myopathic diseases. ${ }^{7}$ However, results can be inconclusive, and variants of uncertain significance (VUS) are frequently identified. When a VUS is recognized, it is important to determine the clinical and pathologic findings associated with that gene mutation and identify the frequency of the VUS in genome databases. If the patient presents with clinical characteristics similar to the ones associated with mutations in that particular gene and the VUS is not present in population databases (or the frequency is lower than $0.01 \%$ ), ${ }^{8}$ the VUS is most likely pathogenic; otherwise, the VUS is probably an incidental finding. Genetic counseling provided by genetic health care professionals should be considered when ordering genetic testing, especially when a VUS is found. ${ }^{9}$ In cases in which genetic testing does not provide an answer, a precise phenotypic characterization of the patient can lead to the diagnosis once the causative gene is discovered. In our case, we determined that the patient's phenotype was consistent with an inherited X-linked vacuolar myopathy before the VMA21 gene was linked to the disease. This helped target the specific mutation once the gene was discovered.

Our patient was diagnosed with XMEA due to a VMA21 mutation. The primary function of VMA21 is to regulate the assembly of the vacuolar ATPase (V-ATPase), which maintains the lysosomal acidity. Therefore, VMA21 mutations cause a rise in the lysosomal $\mathrm{pH}$, which alters the autophagic process and potently induces autophagy. This results in the accumulation of autophagolysosomes with incompletely digested contents. ${ }^{6}$ The histologic hallmark is the presence of numerous autophagic vacuoles with accumulated sarcolemmal proteins and deposition of complement C5b-9. ${ }^{10}$

Classic XMEA affects limb-girdle muscles, predominantly in the lower extremities, and presents during childhood, but neonatal and late-onset cases have also been reported. ${ }^{11,12}$ The progression is very slow, extramuscular organs are not clinically affected, and CK typically ranges from $400 \mathrm{U} / \mathrm{L}$ to greater than 4,000 U/L. Our patient demonstrated minimal progression of the disease over the next 8 years after diagnosis, and he continues to be fully independent. Accurate diagnosis allowed for early diagnosis of XMEA in his second-degree cousin. This emphasizes the importance of genetic counseling in X-linked disorders, especially in female family members of childbearing age who may be asymptomatic carriers.

No specific therapies are available for XMEA. Management is symptomatic including maximization of mobility and reduction of joint contractures. ${ }^{3}$

\section{Study Funding}

No targeted funding reported.

\section{Disclosure}

L. Davalos, J. Janecek, Y. Fudym, and P. McKeever report no disclosures relevant to the manuscript; B.C. Callaghan consults for DynaMed, performs medical legal consultations including consultations for the Vaccine Injury Compensation Program, and receives research support from the American Academy of Neurology. Go to Neurology.org/ $\mathrm{N}$ for full disclosures.

Appendix Authors

\begin{tabular}{lll}
\hline Name & Location & Contribution \\
\hline Long & $\begin{array}{l}\text { University of } \\
\text { Davalos, MD } \\
\text { Arbor }\end{array}$ & $\begin{array}{l}\text { Designed and conceptualized the study } \\
\text { and drafted the manuscript for } \\
\text { intellectual content }\end{array}$ \\
\hline
\end{tabular}




\begin{tabular}{lll} 
Appendix & (continued) & \\
\hline Name & Location & Contribution \\
\hline $\begin{array}{l}\text { Jacqueline } \\
\text { Janecek, MD }\end{array}$ & $\begin{array}{l}\text { University of } \\
\text { Michigan, Ann } \\
\text { Arbor }\end{array}$ & $\begin{array}{l}\text { Major role in the acquisition of data and } \\
\text { drafted the manuscript for intellectual } \\
\text { content }\end{array}$ \\
\hline $\begin{array}{l}\text { Yelena } \\
\text { Fudym, Do }\end{array}$ & $\begin{array}{l}\text { University of } \\
\text { Michigan, Ann }\end{array}$ & $\begin{array}{l}\text { Acquisition of data and revised the } \\
\text { manuscript for intellectual content }\end{array}$ \\
\hline $\begin{array}{l}\text { Paul } \\
\text { McKeever, } \\
\text { MD }\end{array}$ & $\begin{array}{l}\text { University of } \\
\text { Arbor }\end{array}$ & $\begin{array}{l}\text { Acquisition of data and revised the } \\
\text { manuscript for intellectual content }\end{array}$ \\
\hline $\begin{array}{l}\text { Brian C. } \\
\text { Callaghan, } \\
\text { MD }\end{array}$ & $\begin{array}{l}\text { University of } \\
\text { Michigan, Ann }\end{array}$ & $\begin{array}{l}\text { Designed and conceptualized the study } \\
\text { and revised the manuscript for } \\
\text { intellectual content }\end{array}$ \\
\hline
\end{tabular}

\section{References}

1. Hanisch F, Kronenberger C, Zierz S, Kornhuber M. The significance of pathological spontaneous activity in various myopathies. Clin Neurophysiol. 2014;125(7):1485-1490.
2. Mellies U, Lofaso F. Pompe disease: a neuromuscular disease with respiratory muscle involvement. Respir Med. 2009;103(4):477-484.

3. Dowling JJ, Moore SA, Kalimo H, Minassian BA. X-linked myopathy with excessive autophagy: a failure of self-eating. Acta Neuropathol. 2015;129(3): 383-390.

4. Selcen D. Myofibrillar myopathies. Neuromuscul Disord. 2011;21(3):161-171.

5. Prall FR, Drack A, Taylor M, et al. Ophthalmic manifestations of Danon disease. Ophthalmology. 2006;113(6):1010-1013.

6. Ramachandran N, Munteanu I, Wang P, et al. VMA21 deficiency prevents vacuolar ATPase assembly and causes autophagic vacuolar myopathy. Acta Neuropathol. 2013; 125(3):439-457.

7. Winder TL, Tan CA, Klemm S, et al. Clinical utility of multigene analysis in over 25,000 patients with neuromuscular disorders. Neurol Genet. 2020;6(2):e412.

8. Kobayashi Y, Yang S, Nykamp K, Garcia J, Lincoln SE, Topper SE. Pathogenic variant burden in the ExAC database: an empirical approach to evaluating population data for clinical variant interpretation. Genome Med. 2017;9(1):13.

9. Elliott AM, Friedman JM. The importance of genetic counselling in genome-wide sequencing. Nat Rev Genet. 2018;19(12):735-736.

10. Louboutin JP, Villanova M, Ulrich G, De Clerck LS, Fardeau M, Sagniez M. Elevated levels of complement components $\mathrm{C} 5$ and $\mathrm{C} 9$ and decreased antitrypsin activity in the serum of patients with X-linked vacuolated myopathy. Muscle Nerve. 1996;19(9): 1144-1147.

11. Ruggieri A, Ramachandran N, Wang P, et al. Non-coding VMA21 deletions cause X-linked myopathy with excessive autophagy. Neuromusc Disord. 2015;25(3): 207-211.

12. Crockett $\mathrm{CD}$, Ruggieri A, Gujrati $\mathrm{M}$, et al... Late-adult onset of $\mathrm{X}$-linked myopathy with excessive autophagy (XMEA). Muscle Nerve. 2014;50(1):138-144.

\section{Call for Voices: Lived Experiences}

The Editors of the Neurology specialty section Inclusion, Diversity, Equity, Anti-racism, \& Social Justice (IDEAS) encourage you to submit short first-person accounts (1,000 words or less) of experiences lived within the realm of IDEAS with the goal of informing and enlightening our community on these critical issues. Some topics to consider include, but are not limited to:

- Descriptions of personal experiences that shaped your views of IDEAS.

- Reflections on the intersection between personal identity and career.

- Discussions at the intersection of IDEAS and neurology patient care, research, education, advocacy, or policy.

Submit your contributions to journal@neurology.org and include "Voices Submission" in the subject line.

\section{Disputes \& Debates: Rapid Online Correspondence}

The editors encourage comments on recent articles through Disputes \& Debates:

Access an article at Neurology.org/ $N$ and click on "MAKE COMMENT" beneath the article header.

Before submitting a comment to Disputes \& Debates, remember the following:

- Disputes \& Debates is restricted to comments about articles published in Neurology within 6 months of issue date

- Read previously posted comments; redundant comments will not be posted

- Your submission must be 200 words or less and have a maximum of 5 references; the first reference must be the article on which you are commenting

- You can include a maximum of 5 authors (including yourself) 


\section{Neurology}

\section{Clinical Reasoning: A 59-Year-Old Man With Progressive Proximal Weakness Since Childhood}

Long Davalos, Jacqueline Janecek, Yelena Fudym, et al.

Neurology 2021;97;958-963 Published Online before print July 14, 2021

DOI 10.1212/WNL.0000000000012488

\section{This information is current as of July 14, 2021}

\section{Updated Information \&} Services

References

Subspecialty Collections

Permissions \& Licensing

Reprints including high resolution figures, can be found at: http://n.neurology.org/content/97/20/958.full

This article cites 12 articles, 1 of which you can access for free at: http://n.neurology.org/content/97/20/958.full\#ref-list-1

This article, along with others on similar topics, appears in the following collection(s):

Muscle disease

http://n.neurology.org/cgi/collection/muscle_disease

Information about reproducing this article in parts (figures,tables) or in its entirety can be found online at:

http://www.neurology.org/about/about_the_journal\#permissions

http://n.neurology.org/subscribers/advertise

Neurology ${ }^{\circledR}$ is the official journal of the American Academy of Neurology. Published continuously since 1951, it is now a weekly with 48 issues per year. Copyright () 2021 American Academy of Neurology. All rights reserved. Print ISSN: 0028-3878. Online ISSN: 1526-632X.

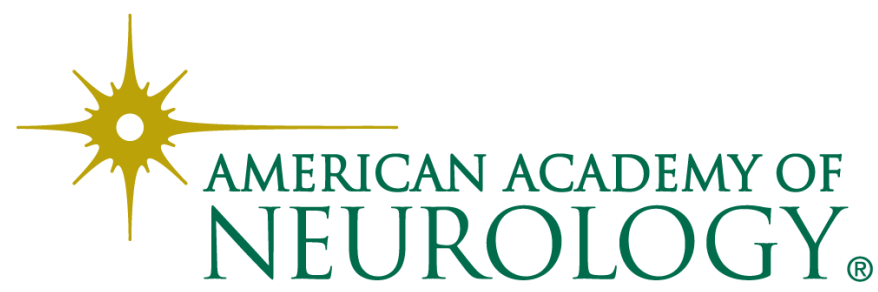

